University of Nebraska - Lincoln

DigitalCommons@University of Nebraska - Lincoln

Publications from USDA-ARS / UNL Faculty

U.S. Department of Agriculture: Agricultural

Research Service, Lincoln, Nebraska

2011

Determination of representative elementary areas for soil redoximorphic features identified by digital image processing

\author{
T. Kevin O'Donnell \\ University of Missouri, odonnell.thomas@epa.gov \\ Keith W. Goyne \\ University of Missouri \\ Randall J. Miles \\ University of Missouri \\ Claire Baffaut \\ USDA - Agricultural Research Service \\ Stephen H. Anderson \\ University of Missouri, andersons@missouri.edu \\ See next page for additional authors
}

Follow this and additional works at: https://digitalcommons.unl.edu/usdaarsfacpub

Part of the Agricultural Science Commons

O'Donnell, T. Kevin; Goyne, Keith W.; Miles, Randall J.; Baffaut, Claire; Anderson, Stephen H.; and Sudduth, Kenneth A., "Determination of representative elementary areas for soil redoximorphic features identified by digital image processing" (2011). Publications from USDA-ARS / UNL Faculty. 869.

https://digitalcommons.unl.edu/usdaarsfacpub/869

This Article is brought to you for free and open access by the U.S. Department of Agriculture: Agricultural Research Service, Lincoln, Nebraska at DigitalCommons@University of Nebraska - Lincoln. It has been accepted for inclusion in Publications from USDA-ARS / UNL Faculty by an authorized administrator of DigitalCommons@University of Nebraska - Lincoln. 
Authors

T. Kevin O'Donnell, Keith W. Goyne, Randall J. Miles, Claire Baffaut, Stephen H. Anderson, and Kenneth A. Sudduth 


\title{
Determination of representative elementary areas for soil redoximorphic features identified by digital image processing
}

\author{
T. Kevin O'Donnell ${ }^{\text {a,* }}$, Keith W. Goyne ${ }^{\text {a }}$, Randall J. Miles ${ }^{\text {a }}$, Claire Baffaut ${ }^{\text {b }}$, \\ Stephen H. Anderson ${ }^{a}$, Kenneth A. Sudduth ${ }^{\text {b }}$ \\ a Department of Soil, Environmental and Atmospheric Sciences, University of Missouri, Columbia, MO 65211, United States \\ ${ }^{\mathrm{b}}$ USDA - Agricultural Research Service, Cropping Systems and Water Quality Research Unit, Columbia, MO 65211, United States
}

\section{A R T I C L E I N F O}

\section{Article history:}

Received 30 July 2010

Received in revised form 6 December 2010

Accepted 7 December 2010

Available online 20 January 2011

\section{Keywords:}

Digital photography

Soil redoximorphic features

Micromorphometry

Image classification

Pedology

Hydric soils

\begin{abstract}
A B S T R A C T
Photography has been a welcome tool in documenting and conveying qualitative soil information. When coupled with image analysis software, the usefulness of digital cameras can be increased to advance the field of micropedology. The determination of a representative elementary area (REA) still remains a critical information need for soil scientists so that field measurements are independent of sample size and account for spatial heterogeneity. An objective of this study was to define and determine an REA for Low Chroma and High Chroma soil redoximorphic features (SRFs) present in claypan soils of northeastern Missouri, USA using a digital camera and image classification techniques. An additional objective was to examine REA differences between these two SRF types, soil depths, and landscape positions to highlight sampling considerations when quantifying SRFs in the field. Three metrics were chosen to quantify SRF heterogeneity, including percent occurrence, mean Euclidean distance, and the Interspersion/Juxtaposition Index. The relative change in these metrics was determined for 16 image sizes ranging from $2.5 \mathrm{~cm}^{2}$ to $40 \mathrm{~cm}^{2}$ and used to identify an REA. Results showed REAs (mean \pm SE) for Low Chroma $\left(17.7 \mathrm{~cm}^{2} \pm 0.4\right)$ and High Chroma $\left(25.4 \mathrm{~cm}^{2} \pm 0.7\right)$ were significantly different $(\alpha=0.05)$. Further review of REAs indicated large sampling diameters $(>8 \mathrm{~cm})$ are necessary to simultaneously capture REAs of Low Chroma and High Chroma SRFs. When SRFs were considered separately, a $\geq 5 \mathrm{~cm}$ diameter core is recommended to reach an REA for Low Chroma, allowing accurate quantification for soil classification purposes and hydric soil determinations. Federal and state agencies requiring quantifiable SRF measures for land management decisions may greatly benefit from determining these minimum measurement scales, ensuring appropriate data collection methods in the future.
\end{abstract}

(c) 2011 Elsevier B.V. All rights reserved.

\section{Introduction}

The choice of a sampling unit used for field collection of soil data is largely left to the discretion of the investigator. A review of U.S. protocols for field soil descriptions offers little to no guidance concerning appropriate sampling units necessary to obtain representative soil attribute data. The definition of a pedon remains an ambiguous and theoretical construct (Holmgren, 1988) with broad area boundaries between 1 and $10 \mathrm{~m}^{2}$ (USDA, 1993). Additionally, 10 of 12 soil horizon attributes recommended for field data collection from horizons do not have a standardized minimum volume/area for data collection nor a method to determine an appropriate sampling unit (Schoeneberger et al., 2002). As exceptions, a $1 \mathrm{~cm}^{2}, 1 \mathrm{dm}^{2}$, or $1 \mathrm{~m}^{2}$ area is recommended for quantifying roots and pores based on three diameter classes of these features (Schoeneberger et al., 2002). The presence of such explicit

\footnotetext{
* Corresponding author. Present Address: U.S. Environmental Protection Agency Great Lakes National Program Office, 77 West Jackson Blvd. (G-17J), Chicago, IL 60604, United States. Tel.: + 13128860813.

E-mail address: odonnell.thomas@epa.gov (T.K. O'Donnell).
}

guidelines is surprising considering the lack of any other comparable specificity for all other soil attribute data. As a result, past and current soil knowledge may be greatly influenced by observer biases and preferred, easily used, or locally adopted sampling methods. These deficiencies are notable given recent calls to integrate existing soil information into large databases for use in pedotransfer functions and regional/global predictions of biogeochemical processes (Lin, 2003; Sanchez et al., 2009).

The representative elementary area (REA) concept, a variant of the representative elementary volume (REV) concept, holds great potential for defining sample units from which to collect soil attribute data. The REV concept has received significant attention from physical scientists since its presentation by Hubbert (1956) and Bear (1972). When applied to a three-dimensional porous medium, the REV concept defines a volume at which increasing sample size and associated soil heterogeneity no longer affect the average value of a measured parameter (Bear and Bachmat, 1984). The parameter of interest has often been pore space and fluid flow processes for soil physics. Hydrologists have extended these principles to watersheds, identifying a two dimensional landscape area (REA) having average 
rainfall, infiltration, and runoff rates relatively constant as increasing areas are considered (Woods et al., 1988). Further application of the REA concept to soils was accomplished by Buchter et al. (1994), relying on soil thin sections to document areal percentage of coarse fragments from soil monoliths. In this case, an REA was visually determined from graphs by noting when oscillation of the mean coarse fragment percentage ceased with increasing area viewed (Buchter et al., 1994). An REA was quantitatively determined by VandenBygaart and Protz (1999) for soil pores observed from prepared thin sections. These authors arbitrarily defined an REA where parameter values did not change more than $\pm 10 \%$ relative to the next greater area in three successive increasing areas of measurement (VandenBygaart and Protz, 1999). Surprisingly, micropedology studies have failed to advance these REA concepts, often assuming sampling area is sufficient to meet particular study objectives (e.g., Holden, 2001; e.g., Adderley et al., 2002; and Adderley et al., 2006).

Micropedology (i.e., micromorphology) studies may be viewed as an extension of field morphological studies, relying on preparation of thin sections for observation of soil features under various magnification scales (Wilding and Flach, 1985). While early interpretations were largely through deduction, intuition, and guess-work using microscopes and hand lens (FitzPatrick, 1993; Stoops, 2009), the adoption of various image capture techniques and analysis software has allowed for more repeatable, consistent identification and quantification of soil fabric units (i.e., micromorphometry; Murphy et al., 1977; Moran et al., 1989; Protz et al., 1992; Terribile and FitzPatrick, 1992; Terribile and FitzPatrick, 1995; and Aydemir et al., 2004). Image scanning equipment and digital cameras have permitted even larger soil areas to be studied and quantified (Buchter et al., 1994; Velde et al., 1996; Levin et al., 2005; van Huyssteen et al., 2006; and Viscarra Rossel et al., 2008). Even so, recent guidelines for preparation of soil areas fail to consider the determination of an REA (e.g., Stoops, 2003; e.g., Vepraskas and Wilson, 2008), drawing into question the adequacy of micropedology studies to achieve their stated objectives (VandenBygaart et al., 2008). If future goals of micropedology are to better bridge gaps between the laboratory and field (Vepraskas and Wilson, 2008) and address practical problems (Mermut, 2009), a determination of REAs that guide field collection of soil attributes serves these aspirations. Applicability of these REA determinations may be further increased by investigating soil attributes currently relied upon by U.S. federal agencies for jurisdictional purposes.

Soil redoximorphic features (SRFs) are morphologic indicators of oxidation-reduction chemical reactions mediated by microbes and resulting from anoxic conditions due to soil saturation. The presence of SRFs has been used by pedologists and field scientists to infer soil moisture regimes for approximately 60 years (Veneman et al., 1998). Quantitative relationships between water table depths and soil redoximorphic features have been documented by various authors (e.g., Zampella, 1994; Genthner et al., 1998; He et al., 2003; and Morgan and Stolt, 2006), suggesting monitoring of water tables may be substituted by field description of SRFs (Vepraskas and Caldwell, 2008). This association of SRFs with soil hydrology has provided U.S. agricultural agencies with field methods necessary for identifying wetlands and enforcing farm commodity programs (e.g., 1985 USDA Farm Bill Swampbuster provisions). Identifying SRFs by color at particular soil depths is also used to indicate hydric soils, one of three landscape features necessary for identification of wetlands by the U.S. Army Corps of Engineers (USACE, 1987; NRCS, 2006).

In addition to identifying SRFs at particular soil depths, field soil scientists are required to estimate SRF percent occurrence to confirm particular hydric soil indicators. The F3: Depleted Matrix indicator is the most commonly observed hydric soil indicator at wetland boundaries and is defined as a soil layer having $\geq 60 \%$ area with Munsell chroma $\leq 2$ (USACE, 2008). Further review of procedures for sampling reveals that no standard viewing area is recommended. Instead, sampling is recommended to a specified depth (approximately $1 \mathrm{~m}$ ) by digging a hole, use of an auger, or use of soil probe
(NRCS, 2006; USACE, 2008). When the REA concept is considered, SRF parameters (e.g., percent occurrence) will vary for a particular soil layer as the differing areas are viewed due to inherent soil heterogeneity. That is to say, one observer may identify a particular hydric soil indicator when a $2 \mathrm{~cm}$ diameter soil core from a push probe is viewed and simultaneously not identify the same indicator when a $20 \mathrm{~cm}$ slice of soil from a shovel is viewed. This potential discrepancy is significant, calling into question hydric soil determinations when no explicit area is included in guidelines for their description.

Against a backdrop of significant hydrologic, water quality, and ecological effects due to extensive wetland losses in North America (Blann et al., 2009), repeatable, consistent, and standardized SRF identification is needed to make future land management decisions more defensible. Micropedologists have already employed image analysis techniques necessary to define REAs for various soil fabric units, yet have not commonly done so. As expressed by VandenBygaart and Protz (1999), knowledge of soil processes and their morphologic indicators across multiple scales is greatly needed in soil science but widely lacking. The overall goals of this study is to continue the discussion of defining REAs for soil fabric units and outline methods micropedologists may use to determine a standardized viewing area for SRFs. A study objective is to define an REA for two SRF types, Low Chroma and High Chroma, based on their percent occurrence, spatial pattern of occurrence, and location relative to adjacent soil fabric units. An additional objective is to quantify REAs for Low Chroma and High Chroma at 6 depth increments from 49 sites and 2 fields located in north central Missouri, USA. A final objective is to investigate the differences between REAs for landscape positions, depths, and SRF types, highlighting considerations when observing SRFs across multiple locations with various sampling devices.

\section{Materials and methods}

\subsection{Study area, soils, and sampling}

Two cropped fields, Fields 1 ( $37 \mathrm{ha}$ ) and 2 (13 ha) located in the U.S. Midwest and within $2 \mathrm{~km}$ of Centralia, $\mathrm{MO}\left(39^{\circ} 13^{\prime} 58^{\prime \prime} \mathrm{N}, 92^{\circ} 07^{\prime}\right.$ $57^{\prime \prime} \mathrm{W}$ ), were selected for this study (Fig. 1). Fields were selected to supplement SRF data collected from this study with existing soil textural data and 1:5000 scale soil mapping. Soils at these fields are classified as Albaqualfs, Epiaqualfs, or Argialbolls (Great Group level, U.S. Soil Taxonomy) and nine of eleven soil series described on these landscapes meet criteria likely for hydric soils (NRCS, 2009). An abrupt textural transition from surface horizons to an argillic horizon whose clay content may increase $100 \%$ relative to the overlying horizon is a prominent feature of these soil landscapes (Myers et al., 2007). Approximately one-half to three-quarters of clay minerals in the argillic horizon are composed of smectite, resulting in up to $40 \%$ volume changes in this horizon during wetting and drying cycles
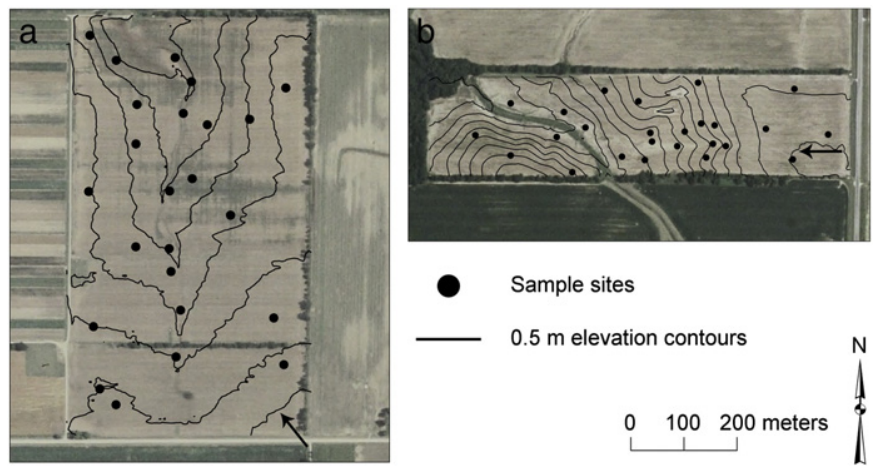

Fig. 1. Study fields and sites used for sampling and determination of Representative Elementary Areas (REAs) for soil redoximorphic features. Field 1 (a) and Field 2 (b) shown. High elevation contour is indicated by an arrow. 
Table 1

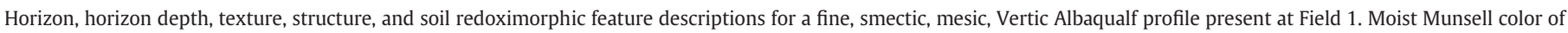
matrix and soil redoximorphic features determined in the field by a human observer is also noted.

\begin{tabular}{|c|c|c|c|c|c|c|c|c|}
\hline \multirow[t]{2}{*}{ Horizon } & \multirow{2}{*}{$\begin{array}{l}\text { Depth } \\
(\mathrm{cm})\end{array}$} & \multirow[t]{2}{*}{ Textural class } & \multirow[t]{2}{*}{ Structure } & \multirow{2}{*}{$\begin{array}{l}\text { Matrix } \\
\text { color }\end{array}$} & \multicolumn{4}{|c|}{ Soil redoximorphic features } \\
\hline & & & & & Type & Quantity, size, contrast & Color & Location \\
\hline Ap & $0-23$ & Silt loam & Weak, fine, granular & 10YR $3 / 2$ & $\mathrm{~N} / \mathrm{A}$ & & & \\
\hline \multirow[t]{3}{*}{$\mathrm{E}$} & $23-28$ & Silty clay loam & Weak, medium, platy \& weak, very fine, subangular blocky & 10YR 4/2 & Concretions & Few, fine ${ }^{a}$ & & Matrix \\
\hline & & & & & Concentrations & Few, fine, faint & $10 Y R 4 / 3$ & Ped faces \\
\hline & & & & & Concentrations & Few, fine, prominent & 5YR 4/6 & Ped faces \\
\hline Bt1 & $28-46$ & Silty clay & Moderate, very fine, subangular blocky & 10YR $4 / 2$ & Concentrations & Few, fine, prominent & 2YR $3 / 6$ & Ped faces \\
\hline Bt2 & $46-58$ & Silty clay & Weak, very fine, subangular blocky & 10YR $4 / 2$ & Concentrations & Few, fine, prominent & 7YR 5/6 & Ped faces \\
\hline Btg3 & $58-97$ & Silty clay & Weak, medium, prismatic \& weak, fine, subangular blocky & $2.5 Y 5 / 2$ & Concentrations & Few, fine, prominent & 10YR $5 / 6$ & Ped faces \\
\hline $\mathrm{BCg} 1$ & $97-127$ & Silty clay loam & Weak, coarse, prismatic \& weak, fine, subangular blocky & $2.5 Y 5 / 2$ & Concentrations & Few, fine, prominent & 10YR 5/6 & Ped faces \\
\hline $\mathrm{BCg} 2$ & $127-152$ & Silty clay loam & Weak, coarse, prismatic \& weak, fine, subangular blocky & $2.5 Y 5 / 2$ & Concentrations & Common, fine, prominent & 10YR 5/6 & Matrix \\
\hline
\end{tabular}

a No contrast for Fe-Mn concretions given.

(Baer and Anderson, 1997). Depth to the argillic horizon ranges from a few centimeters to greater than one meter across these catenas largely due to erosion of loess-derived surface horizons in higher landscape positions and downslope deposition in lower hillslope positions. Soils are commonly referred to as "claypan soils" due to the prominence of this subsurface soil feature and its effects on land management and hydrology. Perched water tables formed during soil recharge (winter through spring) and lateral flow above the argillic horizon have been documented (Minshall and Jamison, 1965; Jamison and Peters, 1967; and Blanco-Canqui et al., 2002).

Prominent SRFs are observed throughout claypan soil profiles. A description of an Albaqualf profile present on a Field 1 summit documented few, fine Fe-Mn concentrations that occurred on surfaces of subangular blocky and prismatic structural units throughout argillic horizons (Table 1). An eluvial horizon located above argillic horizons is characterized by Fe-Mn concretions throughout the matrix as well as differing colored Fe-Mn concentrations located on structural unit surfaces (Table 1). Review of an Epiaqualf profile present on a Field 1 backslope indicated occurrence of Fe-Mn concentrations increase relative to summit landscape positions and remain on ped faces (Table 2 ). While depletions were not noted for profile descriptions made by human observers, image analyses performed by O'Donnell et al. (2010) for these study sites and soils indicated redox depletions were present on ped faces of surface, eluviated, and argillic horizons ranging from $0.09 \%$ to $41 \%$ and moist matrix color was characterized by Chroma $>2$.

A total of 49 cores were collected and analyzed in this study (24 and 25 cores from Field 1 and Field 2, respectively) (Fig. 1). Study sites were selected, in part, due to existing soil textural data and 1:5000 scale soil mapping used to supplement SRF data collected in this study. However, several field sites not previously sampled were included in this study to capture field area observed as "wet" based on visual observations (e.g., standing surface water after rain events) and terrain analysis (e.g., large upslope drainage area). Eight-cm diameter, $120-\mathrm{cm}$ long soil cores were sampled from all sites. This diameter core was the largest diameter practical given available equipment while avoiding excavation of soil pits and excessive disturbance of cropped fields. Soil cores were stored in capped polyethylene terepthalate glycol plastic tubing, transported to a controlled temperature room within $8 \mathrm{~h}$ of collection, and stored at $0{ }^{\circ} \mathrm{C}$. Soil cores were removed from storage $24 \mathrm{~h}$ prior to core description. Soil cores were sectioned and split lengthwise along structural units in the lab. Horizons were described using procedures recommended by Schoeneberger et al. (2002) and existing soil characterization data from sites.

\subsection{Image capture and locations}

A digital camera containing a $3872 \times 2592$ pixel image sensor was used to capture images of exposed core faces, avoiding further preparation and thin sectioning. Exposed cores were placed $25 \mathrm{~cm}$ from the camera setup, resulting in a $700 \mu \mathrm{m}^{2}$ soil area represented by each individual pixel, assuming flat image areas captured. Digital photography was performed in a dark laboratory room. Manual lighting, aperture, and shutter speed settings were used to insure repeatable exposure of images. Further setup and camera settings are detailed in O'Donnell et al. (2010).

Up to six, $40 \mathrm{~cm}^{2}$ digital images $(2277 \times 2277$ pixels $)$ were acquired for each core dependent on the soil horizonation captured by sampling. Maximum image size was $40 \mathrm{~cm}^{2}$ based on diameter of cores used for this study. Imaging of cores began by photographing

Table 2

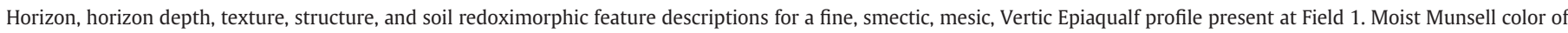
matrix and soil redoximorphic features determined in the field by a human observer is also noted.

\begin{tabular}{|c|c|c|c|c|c|c|c|c|}
\hline \multirow[t]{2}{*}{ Horizon } & \multirow{2}{*}{$\begin{array}{l}\text { Depth } \\
(\mathrm{cm})\end{array}$} & \multirow[t]{2}{*}{ Textural class } & \multirow[t]{2}{*}{ Structure } & \multirow{2}{*}{$\begin{array}{l}\text { Matrix } \\
\text { color }\end{array}$} & \multicolumn{4}{|c|}{ Soil redoximorphic features } \\
\hline & & & & & Type & Quantity, size, contrast & Color & Location \\
\hline Ap & $0-13$ & Silty clay loam & $\begin{array}{l}\text { Weak, very fine, subangular blocky \& } \\
\text { weak, fine, granular }\end{array}$ & 10YR $3 / 2$ & $\mathrm{~N} / \mathrm{A}$ & & & \\
\hline \multirow[t]{2}{*}{ Bt1 } & $13-20$ & Silty clay & Moderate, fine, subangular blocky & 10YR $4 / 2$ & Concentrations & Common, fine, distinct & 10YR $4 / 4$ & Ped faces \\
\hline & & & & & Concentrations & Many, fine, prominent & $5 Y R 4 / 6$ & Ped faces \\
\hline \multirow[t]{2}{*}{ Bt2 } & $20-30$ & Silty clay & Weak, very fine, subangular blocky & 10YR $4 / 2$ & Concentrations & Few, fine, prominent & 5YR $4 / 6$ & Ped faces \\
\hline & & & & & Concentrations & Common, fine, distinct & 10YR $4 / 4$ & Ped faces \\
\hline Btg3 & $30-41$ & Silty clay & Weak, very fine, subangular blocky & 10YR 5/2 & Concentrations & Many, fine, distinct & 10YR $4 / 4$ & Ped faces \\
\hline Btg4 & $41-79$ & Silty clay & $\begin{array}{l}\text { Weak, medium, prismatic \& weak, fine, } \\
\text { subangular blocky }\end{array}$ & $2.5 Y 5 / 2$ & Concentrations & Few, fine prominent & 10YR 5/6 & Ped faces \\
\hline 2BC1 & $79-122$ & Silty clay loam & $\begin{array}{l}\text { Weak, coarse, prismatic \& weak, very fine } \\
\text { and fine, subangular blocky }\end{array}$ & $2.5 Y 5 / 2$ & Concentrations & Common, fine, prominent & 10YR $4 / 6$ & Matrix \\
\hline & & & & & Concentrations & Common, fine, prominent & 10 YR $5 / 8$ & Matrix \\
\hline $2 \mathrm{BC} 2$ & $122-152$ & Silty clay loam & $\begin{array}{l}\text { Weak, coarse, prismatic \& weak, very fine } \\
\text { and fine, subangular blocky }\end{array}$ & $2.5 Y 5 / 2$ & Concentrations & Common, fine, prominent & 10YR $5 / 6$ & Matrix \\
\hline
\end{tabular}


the first argillic horizon, identified as image 00. Four additional images were captured at $11.5 \mathrm{~cm}$ increments below the first argillic horizon, measured from the midpoint of image 00. These images were identified as -1 through -4 . Finally, an image $11.5 \mathrm{~cm}$ above the midpoint of the 00 image was captured if the overlying horizon was described as an E horizon. This image was identified as +1 . Images of A horizons immediately above an argillic horizon were not used for this study to avoid recent management effects on SRFs and REA interpretations. Knowledge of field management practices (Kitchen et al., 2005) and visual inspection of soil cores indicated A horizons immediately above the argillic horizon commonly exhibited properties acquired from tillage, erosion, and deposition processes following row-cropping (e.g., broken horizon boundaries, clods, and weak to moderate platy structure). An $11.5 \mathrm{~cm}$ depth increment was used due to maximum image areas chosen, avoidance of overlapping/adjacent images, and camera setup design. Image depths and horizons were chosen for photography because of the common occurrence of SRFs at these soil profile locations. Depth increments chosen also constituted control sections of soil profiles commonly used for a determination of moisture regime based on U.S. Soil Taxonomy.

\subsection{Soil redoximorphic feature identification and image analysis}

A detailed description of the methods used to identify SRFs from cores is presented in O'Donnell et al. (2010) and is summarized here. Images were stored in 16-bit red, green, and blue (RGB) color space. All image pixels were assigned to 238 possible Munsell soil colors (Hues 10R, 2.5-10 YR, 2.5-5 Y) by a supervised image classification procedure using a minimum spectral distance algorithm. Additionally, thresholding (Lillesand et al., 2004) of spectral distance values enabled identification and representation of soil voids on final classified images. Groups of Munsell soil colors indicative of SRFs were used to identify Low Chroma and High Chroma SRFs (Table 3) based on recommendations by Schoeneberger et al. (2002) and 2332 prior color descriptions of SRFs present in claypan soils (MCSS, 2008). Overall accuracy of SRF identification based on Munsell soil color groups was 99.6\% (O'Donnell et al., 2010). A $6 \times 6$ pixel window, majority function was applied to final classified pixels to remove "saltand-pepper" effects of a pixel by pixel classification and smooth $40 \mathrm{~cm}^{2}$ images (Lillesand et al., 2004; O'Donnell et al., 2010.

Fifteen additional images, ranging from $2.5(570 \times 570$ pixels $)$ to $37.5 \mathrm{~cm}^{2}(2205 \times 2205$ pixels $)$ at $2.5 \mathrm{~cm}^{2}$ increments were created from each classified $40 \mathrm{~cm}^{2}$ image. These fifteen additional image sizes were created by selecting the respective area from each final classified image, centered on the original $40 \mathrm{~cm}^{2}$ image. Creation of additional images allowed the quantification of Low Chroma and High Chroma SRFs for a sequence of image areas necessary for REA determinations (Fig. 2).

\subsection{Using a conceptual model to define an REA}

A definition for an REA was developed by considering a simple, conceptual model of saturation processes occurring in claypan soils and important to SRF formation. Formation of SRFs is proposed to occur largely as a result of seasonal perched water tables (Minshall

Table 3

Groupings of Munsell soil colors used for identification of soil redoximorphic features.

\begin{tabular}{|c|c|c|c|c|}
\hline \multirow{2}{*}{$\begin{array}{l}\text { Soil redoximorphic } \\
\text { feature }\end{array}$} & \multicolumn{3}{|c|}{ Munsell@ } & \multirow{2}{*}{$\begin{array}{l}\text { Common U.S. } \\
\text { terminology }\end{array}$} \\
\hline & Hue & Value & Chroma & \\
\hline Low Chroma & All & $7-4$ & $2-1$ & Redox depletions \\
\hline High Chroma & All & $7-3$ & $8-4$ & Redox concentrations \\
\hline
\end{tabular}

a Schoeneberger, P. J., Wysocki, D. A., Benham, E. C., Broderson, W. D., 2002. Field book for describing soils. Version 2.0, Natural Resources Conservation Service, National Soil Survey Center, Lincoln, Nebraska.

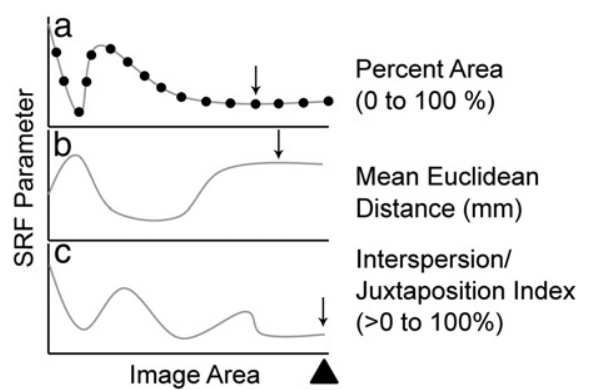

Fig. 2. Graphical representation of determining a Representative Elementary Area (REA) for soil redoximorphic features including examining 16 image sizes from 2.5 to $40 \mathrm{~cm}^{2}(\bullet)$, noting a $< \pm 10 \%$ change in metric values after three successive increases in image area $(\downarrow)$ and the determination of a final REA based on the maximum metric REA $(\boldsymbol{\Lambda})$. Metrics used for final REA include percent area (a), mean Euclidean distance (b), and Interspersion/Juxtaposition Index (c).

and Jamison, 1965; Myers et al., 2007). Oxidation and reduction of particular elements is expected to be closely tied to the location of large clay content horizons and cycling of oxic-anoxic conditions, thus favoring episaturation as a dominant soil and SRF forming process on these low-relief, poorly drained landscapes (Bartelli, 1973). Additionally, transport of reducible elements through pores and along structural voids is expected to be a significant factor in SRF formation due to shrink-swell properties of these soils (Bouma, 1983; Vepraskas, 2001). Depletions (Low Chroma) and concentrations (High Chroma) are expected to co-occur in relation to each other and other soil fabric units (e.g., voids, matrix, etc.). This co-occurrence is confirmed by 162 previous claypan soil descriptions, indicating depletions and concentrations occur together in varying amounts throughout horizons included in this study (MCSS, 2008). Therefore, an REA for SRFs which considers relative occurrence, spatial occurrence, and location relative to other fabric units was proposed.

An REA for Low Chroma and High Chroma was based on three metrics which quantify diagnostic attributes of conceptual SRF formation in claypan soils including (1) percent area, (2) mean Euclidean distance, and (3) the Interspersion/Juxtaposition Index (IJI). Percent area is calculated by quantifying fabric unit area relative to the image area, expressed as a value ranging from 0 to $100 \%$. Mean Euclidean distance quantifies the mean distance among discrete fabric units, measured in millimeters. The IJI quantifies the evenness or clumping of all soil fabric units in the image area investigated, ranging in value from greater than 0 to $100 \%$. Greater IJI values indicate fabric units are more evenly distributed across the area viewed (McGarigal and Marks, 1995). Percent area and mean Euclidean distance were calculated for Low Chroma and High Chroma, separately. The IJI was calculated for the complete image, taking into account all soil fabric units identified by image analysis. Fabric units considered in the IJI included the Matrix, Voids, High Chroma, Low Chroma, and Low Value/Chroma identified during the image analysis using procedures detailed in O'Donnell et al. (2010).

The three REA metrics were calculated for each sequence of 16 image sizes from 2.5 to $40 \mathrm{~cm}^{2}$ (Fig. 2.). A metric REA was identified separately for Low Chroma or High Chroma after (1) three successive increases of image area resulted in parameter values that did not change $\pm 10 \%$ relative to next greater image area and (2) parameter values did not change $\pm 10 \%$ for all remaining (i.e., larger) image increments (Fig. 2). This REA definition builds upon the criteria proposed by VandenBygaart and Protz (1999) and requires increasing image areas to not affect parameters after a temporary plateau in values is reached (e.g., Fig. 2b). A final REA was reached for Low Chroma or High Chroma only after percent area, mean Euclidean distance, and the IJI met these requirements. A final REA was identified as the maximum REA of the three component metrics (Fig. 2c). Ten $\mathrm{cm}^{2}$ was the minimum and $40 \mathrm{~cm}^{2}$ was the maximum final REA based on image areas used and REA criteria. Percent of 
images meeting the final REA for Low Chroma and High Chroma by depth increments ( +1 through -4 ) were determined to investigate sampling efficiency of $8 \mathrm{~cm}$ diameter cores in capturing this minimum sampling area.

\subsection{Sampling device and REA comparisons}

Final REA of each image $\left(\mathrm{cm}^{2}\right)$ was divided by the thickness of the corresponding described horizon $(\mathrm{cm})$ to calculate the minimum sampling diameter $(\mathrm{cm})$ needed to capture a REA. An assumption of isotropy between horizontal and vertical soil image dimensions was made for these calculations. These determinations allowed investigation of sampling method effects on reaching an REA for horizons included in this study and commonly encountered during field descriptions of these soils (E, Bt, and Btg horizons). Only images not crossing horizon boundaries were used for these calculations. Minimum sampling diameters were compared to a standard push probe $(2 \mathrm{~cm})$ and a hydraulic probe $(5 \mathrm{~cm})$ diameter to determine percent of horizons and sites for which a minimum sampling diameter was $\leq 2$ or $\leq 5 \mathrm{~cm}$.

A comparison of REA means among landscape positions, depth increments, and SRF type was performed using a split-split-plot analysis of variance (ANOVA) statistical design specified by the Proc MIXED procedure of SAS (Littell et al., 2007). Soil series determined by a 1:5000 scale soil survey of Fields 1 and 2 served as a proxy of landscape position for this analysis. Pairwise differences of REA means were considered a priori using a Tukey-Kramer adjustment of p-values. Pairwise differences of least squares means were considered significant at $\alpha=0.05$ level.

\section{Results}

\subsection{Images used and final REA summary statistics}

A total of 234 images were used in the REA analysis, ranging from 28 to 48 per depth increment (Table 4). Low Chroma was identified from all samples. A total of 227 of 234 images (97\%) used for this REA analysis contained High Chroma based on image analyses.

Mean depth to first argillic was $37 \mathrm{~cm}(\mathrm{SE} \pm 3.9)$ and ranged from 5 to $110 \mathrm{~cm}$. Fifteen of 49 sites sampled contained the complete set of 6 depth increments used by this study based on depth to the first argillic horizon and horizonation captured by cores. Twenty-two sites contained 5 depth increments and the remaining 12 sites contained $\leq 4$ depth increments.

Review of final REAs indicated $66 \%$ of all images reached an REA for SRF types present (Low Chroma and/or High Chroma) based on a maximum $40 \mathrm{~cm}^{2}$ image area used in this study. When SRF types were considered separately, Low Chroma reached an REA for 98\% of images and High Chroma reached an REA for $65 \%$ of images. Closer inspection of image depths indicated percent of images reaching REA for Low Chroma ranged from $96 \%$ to $100 \%$ (Table 4). Percent of image depths reaching a High Chroma REA ranged from $60 \%$ to $74 \%$. Thirteen of 49 sites (27\%) reached an REA for SRF types present, a $40 \mathrm{~cm}^{2}$ maximum

Table 4

Number of images used and meeting a representative elementary area summarized by depth increments and presence of soil redoximorphic features.

\begin{tabular}{|c|c|c|c|c|c|}
\hline \multirow[t]{2}{*}{ Image depth } & \multirow[t]{2}{*}{ Images used } & \multicolumn{2}{|c|}{ Low Chroma } & \multicolumn{2}{|c|}{ High Chroma } \\
\hline & & $\mathrm{n}$ & REA met & $\mathrm{n}$ & REA met \\
\hline+1 & 28 & 28 & 27 & 27 & 17 \\
\hline 0 & 48 & 48 & 46 & 47 & 32 \\
\hline-1 & 46 & 46 & 45 & 43 & 26 \\
\hline-2 & 40 & 40 & 40 & 39 & 23 \\
\hline-3 & 38 & 38 & 38 & 37 & 24 \\
\hline-4 & 34 & 34 & 33 & 34 & 25 \\
\hline Totals & 234 & 234 & 229 & 227 & 147 \\
\hline
\end{tabular}

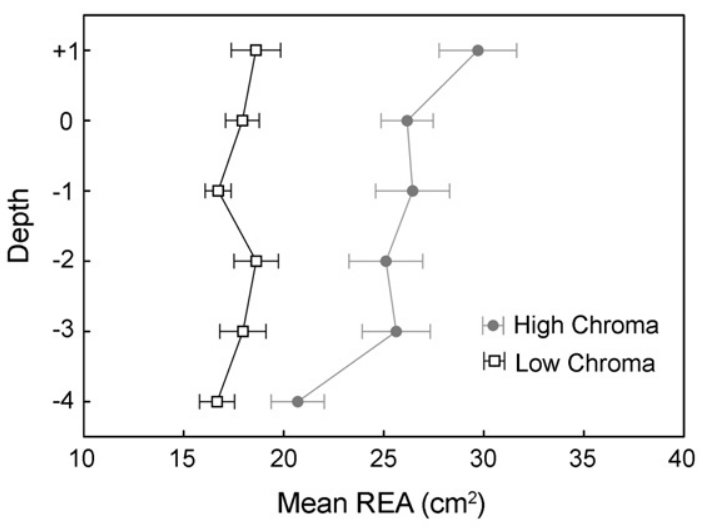

Fig. 3. Arithmetic mean and standard error of Low Chroma and High Chroma Representative Elementary Areas (REAs) summarized by depth increments.

image area considered, and all included depth increments. This small percentage was due largely to images not meeting REAs for High Chroma. A total of 45 of 49 sites (92\%) reached an REA for all depth increments when only Low Chroma was considered.

Arithmetic mean REAs for Low Chroma and High Chroma were $17.7 \mathrm{~cm}(\mathrm{SE} \pm 0.4)$ and $25.4 \mathrm{~cm}(\mathrm{SE} \pm 0.7)$, respectively. Closer inspection of REA for Low Chroma indicated mean values for depth increments were less than $20 \mathrm{~cm}^{2}$ (Fig. 3). Mean REA for Low Chroma ranged from 16.7 to $18.6 \mathrm{~cm}^{2}$. In contrast, mean REAs of High Chroma were greater than $20 \mathrm{~cm}^{2}$, ranging from 20.7 to $29.7 \mathrm{~cm}^{2}$ for the six depth increments (Fig. 3). The greatest mean REA values for Low Chroma and High Chroma both occurred at the +1 depth (i.e., E horizon overlying the first argillic horizon). The least mean REA values for Low Chroma and High Chroma both occurred at the -4 depth (Fig. 3).

\subsection{Component metrics used for final REAs}

Review of metric plots for image sizes ranging from 2.5 to $40 \mathrm{~cm}^{2}$ documented changing parameter values as image size considered was increased at $2.5 \mathrm{~cm}^{2}$ intervals (Figs. 4-6). Examination of component metrics used for a final REA determination indicated 73\% (167 of 229) of Low Chroma REAs were based on one of the three metrics used, as opposed to two or more metrics sharing the same maximum metric REA (Fig. 2). The IJI solely determined the final Low Chroma REA for 106 of these 167 images (Fig. 4). Mean Euclidean distance determined the final Low Chroma REA for 1 of these 167 images (Fig. 5). Seventyseven percent of High Chroma REAs were based on one of the three metrics used. In contrast to Low Chroma, mean Euclidean distance determined the final High Chroma REA for 51 of these 113 images.

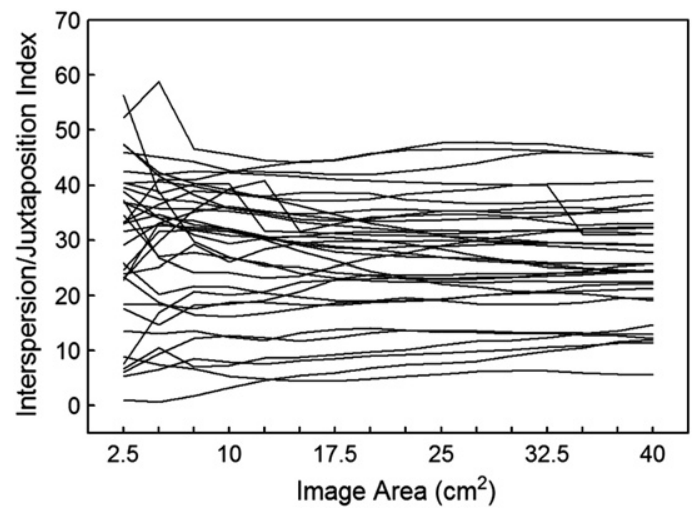

Fig. 4. Plots of the Interspersion/Juxtaposition Index for image sequences examined at the -4 depth increment. Each line represents a sample. Sixteen image sizes, 2.5 to $40 \mathrm{~cm}^{2}$, at $2.5 \mathrm{~cm}^{2}$ area increments shown. 


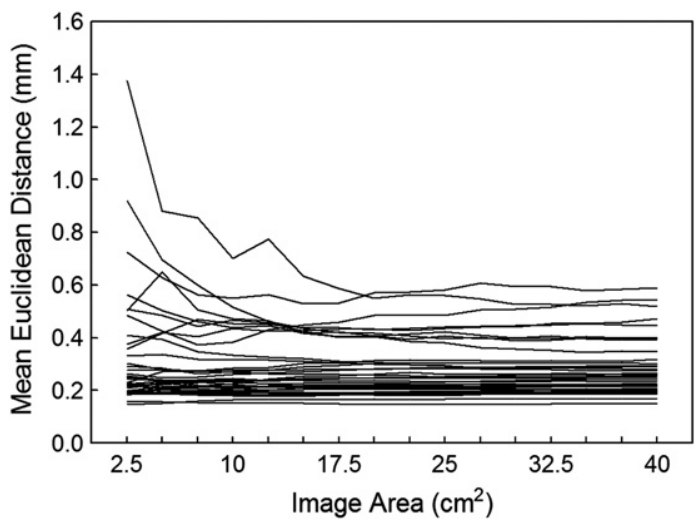

Fig. 5. Plots of Low Chroma mean Euclidean distance for image sequences examined at the -2 depth increment. Each line represents a sample. Sixteen image sizes, 2.5 to $40 \mathrm{~cm}^{2}$, at $2.5 \mathrm{~cm}^{2}$ area increments shown.

Additionally, percent area determined the final High Chroma REA for 48 of 113 images (Fig. 6).

Five images did not meet a Low Chroma REA and 80 images did not meet a High Chroma REA based on the $8 \mathrm{~cm}$ diameter core and REA definitions used by this study. The five images that did not meet a final Low Chroma REA also did not meet a final High Chroma REA. Four of five images not meeting a final Low Chroma REA did not reach an REA for the IJI metric. Inspection of images not meeting a High Chroma REA showed most (65\%) failed to meet one of the three component metric REAs. This metric was most often mean Euclidean distance (39 of 52) followed by percent area (12 of 52).

\subsection{REA sampling effects and mean differences}

Examination of sampling effects on the ability to capture REAs indicated Low Chroma REAs are reached greater than three-quarters of the time when horizons are considered separately and a push probe is used (Table 5). More than doubling the sampling diameter from a $2 \mathrm{~cm}$ push probe to a $5 \mathrm{~cm}$ hydraulic core results in capturing a Low Chroma REA for greater than 95\% of horizons. However, approximately two-thirds of horizons reach a High Chroma REA when the same $5 \mathrm{~cm}$ sampling diameter is used (Table 5). Less than one-third of $\mathrm{E}$ and Btg horizons reach a High Chroma REA when a $2 \mathrm{~cm}$ push probe is used for sampling. When horizons are considered as a continuous vertical sequence captured by a $2 \mathrm{~cm}$ soil probe, less than $50 \%$ and less than $10 \%$ of sites reach an REA for Low Chroma and High Chroma, respectively. The use of a $5 \mathrm{~cm}$ hydraulic core resulted in capturing a Low Chroma REA for $90 \%$ of sites when all horizons were considered

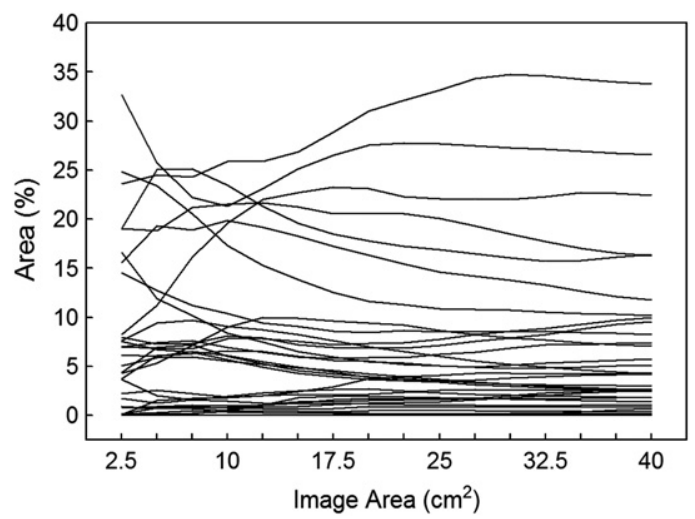

Fig. 6. Plots of High Chroma area for image sequences examined at the -4 depth increment. Each line represents a sample. Sixteen image sizes, 2.5 to $40 \mathrm{~cm}^{2}$, at $2.5 \mathrm{~cm}^{2}$ area increments shown.
Table 5

Percent of images meeting a Representative Elementary Area (REA) for two sampling diameters (2 and $5 \mathrm{~cm}$ ) and soil redoximorphic features (Low Chroma and High Chroma). Percentages are summarized by described horizons and a continuous vertical sequence of horizons captured in a soil core sample.

\begin{tabular}{|c|c|c|c|c|c|c|}
\hline \multirow[b]{2}{*}{ Horizon(s) } & \multicolumn{3}{|c|}{ Low Chroma } & \multicolumn{3}{|c|}{ High Chroma } \\
\hline & $\mathrm{n}$ & $\begin{array}{l}\text { Push probe } \\
(2 \mathrm{~cm})\end{array}$ & $\begin{array}{l}\text { Hydraulic core } \\
(5 \mathrm{~cm})\end{array}$ & $\mathrm{n}$ & $\begin{array}{l}\text { Push probe } \\
(2 \mathrm{~cm})\end{array}$ & $\begin{array}{l}\text { Hydraulic core } \\
(5 \mathrm{~cm})\end{array}$ \\
\hline $\mathrm{E}$ & 28 & $77 \%$ & $98 \%$ & 27 & $32 \%$ & $62 \%$ \\
\hline $\mathrm{Bt}$ & 105 & $91 \%$ & $97 \%$ & 104 & $55 \%$ & $65 \%$ \\
\hline Btg & 101 & $86 \%$ & $96 \%$ & 96 & $26 \%$ & $63 \%$ \\
\hline $\begin{array}{r}\text { Continuous } \\
\text { sequence }\end{array}$ & 49 & $43 \%$ & $90 \%$ & 49 & $8 \%$ & $22 \%$ \\
\hline
\end{tabular}

as a sequence (Table 5). In contrast, $78 \%$ sites do not reach a High Chroma REA when a $5 \mathrm{~cm}$ diameter core is used (Table 5).

Review of ANOVA results and respective least squares means showed High Chroma REA was significantly greater than Low Chroma for most image depths and all landscape positions examined by this study (Table 6 ). Only REAs at the -4 depth were not significantly different between Low Chroma and High Chroma. Overall, High Chroma REA was $8.6 \mathrm{~cm}^{2}$ greater than Low Chroma REA. Greatest difference in REAs based on depth increments was at the +1 depth and was $13.3 \mathrm{~cm}^{2}$ (Table 6). High Chroma REA was greater than $30 \mathrm{~cm}^{2}$ at the +1 depth. In general, differences between Low Chroma and High Chroma REAs decreased with soil depth. The greatest difference between Low Chroma and High Chroma REAs based on landscape position was at the summit and was $10.9 \mathrm{~cm}^{2}$. The least REA difference for SRF types based on landscape position was at the backslope (Table 6).

\section{Discussion}

\subsection{Considerations when defining an REA}

This study highlights the benefits of both a conceptual and quantitative approach to defining REAs for soil fabric units. In the absence of multi-scale measurements of soil properties and processes important to understanding SRF formation (e.g., $\mathrm{pH}$, Eh, organic matter content, water content, and temperature), a simple conceptual model based on episaturation was considered for these soils, then used to formulate a quantitative REA definition. Just as conceptual models of landscape-scale processes have provided guidance to soil surveyors (Hudson, 1992), a profile- and micro-scale conceptual model identified three metrics necessary to accomplish objectives of this study. Indeed, micropedologists working in a lab setting have much to gain from employing techniques relied on by traditional

Table 6

Least squares REA means for selected ANOVA effects and interaction terms. Across a row, REA means with different letters are significantly different $(\alpha=0.05)$.

\begin{tabular}{lll}
\hline ANOVA Effect & Low Chroma $\left(\mathrm{cm}^{2}\right)$ & High Chroma $\left(\mathrm{cm}^{2}\right)$ \\
\hline $\begin{array}{l}\text { SRF } \\
\text { Depthpe }\end{array}$ & $18.0 \mathrm{a}$ & $26.6 \mathrm{~b}$ \\
$\quad+1$ & $17.9 \mathrm{a}$ & $31.2 \mathrm{~b}$ \\
00 & $18.2 \mathrm{a}$ & $27.2 \mathrm{~b}$ \\
-1 & $16.9 \mathrm{a}$ & $27.3 \mathrm{~b}$ \\
-2 & $19.5 \mathrm{a}$ & $27.7 \mathrm{~b}$ \\
-3 & $18.7 \mathrm{a}$ & $24.7 \mathrm{~b}$ \\
-4 & $17.1 \mathrm{a}$ & $21.6 \mathrm{a}$ \\
Landscape position & & \\
Summit & $18.7 \mathrm{a}$ & $29.6 \mathrm{~b}$ \\
Shoulder & $17.3 \mathrm{a}$ & $25.9 \mathrm{~b}$ \\
Backslope & $16.8 \mathrm{a}$ & $23.5 \mathrm{~b}$ \\
Footslope & $19.4 \mathrm{a}$ & $27.5 \mathrm{~b}$
\end{tabular}

a Soil redoximorphic feature. 
pedologists in the field. At the same time, micropedologists must not be blinded by one particular model and fail to consider differing processes important to current observations of soil fabric units (Schaetzl and Anderson, 2005). While not an objective of this study, micropedologists may wish to define multiple REAs for the same soil parameter based on more than one conceptual model, then determine possible REA differences based on additional metrics, classic statistics, and hypothesis testing. In doing so, micropedologists can take advantage of the multitude of quantitative measures produced by micromorphometry studies and continue the discussion of defining an REA for soil fabric units.

Results from this study draw attention to the lack of previous studies conducted to define an REA and no standard REA protocol currently used. Specifically, maximum image area used and successive increases in image area should be thoroughly considered when defining an REA for future studies. Sweeney (1994) used a maximum thin section area of $5.91 \mathrm{~cm}^{2}(510 \times 510$ pixels $)$ to determine an REA for soil pores. Image sequences were based on pixel dimensions, sequentially increasing both dimensions by 50 pixels (Sweeney, 1994). VandenBygaart and Protz (1999) relied on rectangular thin sections and a maximum image size of $16.5 \mathrm{~cm}^{2}(2815 \times 3760$ pixels $)$ during an REA analysis of soil pores. Difference in sequential image areas was not constant and ranged from 0.3 to greater than $3 \mathrm{~cm}^{2}$ (VandenBygaart and Protz, 1999). In contrast to these studies, a maximum image size of $1225 \mathrm{~cm}^{2}$ was used to determine REAs for coarse fragments in soil monoliths. Pixel size was $1 \mathrm{~cm}^{2}$ and images were increased by 2 pixels for each dimension between sequential images (Buchter et al., 1994).

A review of these studies indicates choice of image sizes was based largely on sample preparation common to micropedology studies. Reliance on Kubiëna tins for soil sampling and preparation of traditional soil thin sections may limit image area based on microscope viewing of soil fabric units. Thin sections used for micropedology studies commonly range between 13 and $38 \mathrm{~cm}^{2}$ (Vepraskas and Wilson, 2008). The use of additional imaging equipment (e.g., scanners, digital cameras) now allows greater areas to be captured, as demonstrated by Buchter et al. (1994). While methods used in this study are based on $8 \mathrm{~cm}$ cores and a maximum image area of $40 \mathrm{~cm}^{2}$, the use of a larger maximum image area is possible but expected to result in variable REAs for the same soil parameters (Hillel, 2003). Additionally, altering areal differences between image sequences from $2.5 \mathrm{~cm}^{2}$ to greater or lesser values may also result in variable REAs. In this case, results presented here may be viewed as a first approximation of an REA for Low Chroma and High Chroma present in claypan soils of northeastern Missouri, USA. Future studies may investigate the robustness of REA values for a particular soil fabric unit by altering maximum image areas used for particular soil fabric units. Such considerations are common to the field of landscape ecology, recognizing the effect of grain (i.e., pixel dimensions) and spatial extent (i.e., maximum study area) on study results (Turner, 1989; Levin, 1992).

The definition of an REA proposed here differs from that presented by VandenBygaart and Protz (1999) by requiring parameter values to not change $\pm 10 \%$ for all other increasing area increments up to the maximum image area $\left(40 \mathrm{~cm}^{2}\right)$. This definition recognizes a "temporary microscopic REA" may exist (Fig. 2b) and three successive images of increasing area may not sufficiently capture soil heterogeneity important to soil fabric units. This inability to capture soil heterogeneity in successive images may be due in part to area increments used for image sequences $\left(2.5 \mathrm{~cm}^{2}\right)$. Additionally, representation of three dimensional soil fabric units in two dimensions can result in incorrect interpretations of geometry and resulting quantitative measures (Stoops, 2003). Finally, all possible soil fabric units of interest may not be contained by small image sizes, affecting selected metrics (e.g., IJI). When these factors were considered, a stricter definition of an REA for SRFs was chosen. At the same time, it was assumed that $8 \mathrm{~cm}$ diameter cores captured one unique pedon. As increasing areas are considered for future REA analyses, the chance of including multiple pedons in images may be increased. In the absence of definitive methods to identify pedon boundaries, future studies must consider whether heterogeneity observed in soil samples of a given area is a function of microscopic (e.g., within pedon) or macroscopic factors (e.g., across pedon), then define REAs accordingly.

\subsection{Implications for soil sampling, mapping, and hydric soils in Missouri, USA}

Review of ANOVA results (Table 6) confirmed REAs can differ between soil fabric units (Bear and Braester, 1972; Hillel, 2003). Differences between Low Chroma and High Chroma REAs were also present at most depth increments and all landscape positions (Table 6). An examination of sampling effects on REAs showed a study objective to quantify Low Chroma and High Chroma at multiple depths across claypan soil landscapes would not be well matched with use of standard push probe (Table 5). These results stress the importance of determining REAs first by micromorphometry studies, then matching study objectives for a particular soil parameter(s) with an appropriate field sampling method.

Furthermore, an objective to use previously collected Low Chroma and High Chroma data obtained from multiple sampling methods (i.e., areas considered) in predictions of hydrologic regime or saturation would be ill advised for northeastern Missouri claypan soils. Image sequences showed differences in percent occurrence of SRFs (Low Chroma and High Chroma) can range up to $32 \%$ for one unique sample based on the area considered $\left(2.5\right.$ to $40 \mathrm{~cm}^{2}$ ). As calls for synthesis of existing soil information into global databases are considered (Sanchez et al., 2009), results from this study indicate an initial metadata analyses focused on determining the range of sampling volumes/areas used for previous data collection is critical.

The poor ability to capture REAs for a complete vertical sequence of depth increments $(+1$ through -4$)$ and sites considered by this study is noteworthy given the use of SRFs for soil classification purposes (Table 5). A review of 162 pedons sampled from claypan soil associations in Missouri, USA indicated 133 were classified as Aqualfs (Suborder level, U.S. Soil Taxonomy). Further review of these pedons showed 99 of $133(74 \%)$ were sampled by use of a soil core ranging from $2.5 \mathrm{~cm}$ to $7.5 \mathrm{~cm}$ in diameter (personal communication, G. Butler, U.S. Department of Agriculture Natural Resources Conservation Service, April 1, 2010). U.S. classification of soils to the Aqualf suborder requires enough active ferrous iron for a positive reaction to alpha,alpha dipyridyl ((USDA), 1999). Alternatively, classification is based on the presence of SRFs at a depth between the lower boundary of the Ap horizon or a $25 \mathrm{~cm}$ depth, whichever is deeper, and $40 \mathrm{~cm}$ ((USDA), 1999). This general SRF presence must be accompanied by a determination of at least $50 \%$ of redox depletions having a chroma 2 or less on the faces of peds or in the matrix within the upper $12.5 \mathrm{~cm}$ of the argillic horizon.

When only the 00 and -1 depth increments encompassing the upper $12.5 \mathrm{~cm}$ of the argillic horizon were considered as a continuous vertical sequence, $70 \%$ of the sites used by this study would reach an REA when sampled with a $2.5 \mathrm{~cm}$ probe. The probability of reaching an REA for 00 and -1 depth increments for sites increased to $97 \%$ when a $7.5 \mathrm{~cm}$ diameter is used. In this case, the choice of a 2.5 to $7.5 \mathrm{~cm}$ diameter probe would result in most sites reaching an REA for depths used for Suborder classification. While pedons used for this study were not classified by earlier surveys, these results point to the uncertainty of Missouri claypan soil classification that can be quantified by REA studies prior to initiating field studies and choosing field sampling methods. It is not expected that every soil sample used for mapping and classification purposes should be large enough to include REAs. However, results presented here encourage the alternating use of large sample areas (e.g., large diameter cores, soil 
pits) with smaller "reconnaissance sampling" (e.g., small diameter probes) when mapping and classifying northeastern Missouri soils to reduce uncertainties.

Sites used by this study did not meet technical standards for hydric soil indicators due to thickness/color of surface horizons (USACE, 2008). However, a depleted matrix below surface horizons was commonly observed based on image analyses. A depleted matrix having $\geq 60 \%$ of area whose color is Munsell chroma $\leq 2$ is a requirement for four separate hydric soil indicators used in the U.S. Midwest including the most common (e.g., F3: Depleted Matrix, USACE, 2008). Further review of images indicated four sites met the requirement of $\geq 60 \%$ Low Chroma at the $40 \mathrm{~cm}^{2}$ image area. Sites were located on each field and occurred in depositional footslopes or adjacent to waterways/concentrated flow areas. Two of four sites would be incorrectly characterized as having a matrix with $<60 \%$ Munsell chroma $\leq 2$ when an area less than the REA was viewed. The probability of incorrectly characterizing these northeastern Missouri sites was $57 \%$ and $100 \%$ when these reduced image areas were considered.

These probabilities of misclassifying a requirement for the most common hydric soil indicator may not be tolerated by land owners or agencies seeking to accurately delineate and protect northeastern Missouri wetlands. Results presented here are directly relevant to northeastern Missouri soils and similar claypan soils occupying 4 million hectares of the Midwest USA (Anderson et al., 1990). Consequently, a determination of REAs by micromorphometry studies may be necessitated prior to field investigations in these regions so jurisdictional decisions rest on defensible sampling protocols. For other soils occurring outside the Midwest USA and experiencing similar episaturation processes, this study encourages scientists to adopt similar micromorphometry approaches to determine appropriate sample areas used for soil descriptions and more fully integrate micropedology with field surveys. Such efforts would be expected to greatly benefit global efforts to accurately identify, protect, and restore wetlands while continuing the discussion of defining REAs for soil fabric units.

\section{Conclusions}

The REAs of Low Chroma and High Chroma SRFs present in northeastern Missouri claypan soils were determined based on previous attempts to document a volume/area at which the quantification of soil properties becomes independent of spatial heterogeneity. This REA method relied on exposed soil cores and the use of three metrics to achieve study objectives. Percent occurrence, mean Euclidean distance, and the Interspersion/Juxtaposition Index were used as measures of SRF heterogeneity based on a conceptual model of soil forming processes in landscapes of northcentral Missouri, USA. This initial consideration of soil forming processes important to SRFs provided a useful approach for future quantitative micropedology studies investigating these and other fabric units. Additionally, image analysis of SRFs did not require preparation of soil thin sections, reducing time necessary to generate results. This efficient determination of REAs motivates greater integration of micromorphometry studies conducted in a lab setting with soil surveys and mapping. Results presented here highlight information needs this REA analysis can address prior to field soil data collection: (1) an empirical determination of minimum soil areas necessary to quantify fabric units and (2) an appropriate sampling method that matches this determination.

Study results showed a sampling diameter of $5 \mathrm{~cm}$ is recommended for quantification of Low Chroma in northeastern Missouri claypan soil horizons. However, an REA for High Chroma was reached for approximately two-thirds of images analyzed, indicating that an $8 \mathrm{~cm}$ core is not large enough to allow consistent determinations of both types of SRFs found in these soils. Therefore, a study objective to quantify multiple SRFs must balance sampling effort needed to reach multiple REAs at each horizon/site with usefulness of data. Accurate quantification of Low Chroma SRFs currently outweighs quantification of High Chroma SRFs for northeastern Missouri soils based on U.S. Soil Taxonomy and wetland delineation methods. Review of image sequences used for REA determinations of individual images (2.5 to $40 \mathrm{~cm}^{2}$ ) indicated percent Low Chroma varied across threshold values commonly used for soil classification $(>50 \%)$ and hydric soil indicators $(\geq 60 \%)$. While soil scientists may integrate large and small diameter sampling methods to reduce uncertainty of soil surveys, little to no uncertainty may be tolerated when hydric soil determinations are conducted. In this case, REA determinations for SRFs may be a critical first step in northeastern Missouri wetland delineations.

\section{Acknowledgements}

The authors thank Dr. Newell Kitchen, Matt Volkmann, Bob Mahurin, and Kurt Holliman, USDA-ARS Cropping Systems and Water Quality Research Unit, Columbia MO USA, for assistance with soil sampling and access to ARS research fields. David Rees, University of Missouri Department of Photojournalism, provided guidance in selection of digital camera equipment. Jennifier Goyne, Center for Applied Research and Environmental Systems, University of Missouri, Columbia, MO USA, provided assistance in constructing automated image processing programs.

Funding for this research was provided by the University of Missouri Research Council (Grant \# URC-08-046) and the USDA-CSREES, National Integrated Water Quality - Conservation Effects Assessment Project (CEAP) (Grant \# 2005-51130-02380).

\section{References}

Adderley, W.P., Simpson, I.A., Davidson, D.A., 2002. Colour description and quantification in mosaic images of soil thin sections. Geoderma 108, 181-195.

Adderley, W.P., Simpson, I.A., Davidson, D.A., 2006. Historic landscape management: a validation of quantitative soil thin-section analyses. Journal of Archaeological Science 33, 320-334.

Anderson, S.H., Gantzer, C.J., Brown, J.R., 1990. Soil physical properties after 100 years of continuous cultivation. Journal of Soil and Water Conservation 45, 117-121.

Aydemir, S., Keskin, S., Drees, L.R., 2004. Quantification of soil features using digital image processing techniques. Geoderma 119, 1-8.

Baer, J.U., Anderson, S.H., 1997. Landscape effects on desiccation cracking in an Aqualf. Soil Science Society of America Journal 61, 1497-1502.

Bartelli, L.J., 1973. Soil development in loess in the southern Mississippi Valley. Soil Science $115,254-260$

Bear, J., 1972. Dynamics of Fluids in Porous Media. Elsevier, New York City, New York.

Bear, J. Bachmat, Y., 1984. Transport phenomenon in porous media - basic equations. In: Bear, J., Corapcioglu, M.Y. (Eds.), Fundamentals of Transport Phenomenon in Porous Media, NATO ASI Series, pp. 3-62.

Bear, J., Braester, C., 1972. On the flow of two immiscible fluids in fractured porous media. First Symposium on Fundamentals of Transport Phenomena in Porous Media. Developments in Soil Science. Elsevier, New York City, New York.

Blanco-Canqui, H., Gantzer, C.J., Anderson, S.H., Alberts, E.E., Ghidey, F., 2002. Saturated hydraulic conductivity and its impact on simulated runoff for claypan soils. Soil Science Society of America Journal 66, 1596-1602.

Blann, K.L., Anderson, J.L., Sands, G.R., Vondracek, B., 2009. Effects of agricultural drainage on aquatic ecosystems: a review. Critical Reviews in Environmental Science and Technology 39, 909-1001.

Bouma, J., 1983. Hydrology and soil genesis of soils with aquic moisture regimes. In: Smeck, N.E., Hall, G.F. (Eds.), Pedogenesis and Soil Taxonomy. Elsevier Science Publishers, Amsterdam, Netherlands, pp. 253-281.

Buchter, B., Hinz, C., Flühler, H., 1994. Sample size for determination of coarse fragment content in a stony soil. Geoderma $63,265-275$.

Department of Agriculture Soil Survey Staff (USDA), 1993. Soil Survey Manual. Soil Conservation Service. U.S. Department of Agriculture Handbook 18, U.S. Department of Agriculture, Washington, D.C.

FitzPatrick, E.A., 1993. Soil Microscopy and Micromorphology. John Wiley \& Sons, Chichester, United Kingdom.

Genthner, M.H., Daniels, W.L., Hodges, R.L., Thomas, P.J., 1998. Redoximorphic features and seasonal water table relations, upper Coastal Plain, Virgina. In: In: Rabenhorst, M.C., Bell, J.C., McDaniel, P.A. (Eds.), Quantifying Soil Hydromorphology. SSSA Special Publication Number 54. Soil Science Society of America, pp. 43-60.

He, X., Vepraskas, M.J., Lindbo, D.L., Skaggs, R.W., 2003. A method to predict soil saturation frequency and duration from soil color. Soil Science Society of America Journal 67, 961-969. 
Hillel, D., 2003. Introduction to Environmental Soil Physics. Elsevier, Amsterdam, Netherlands.

Holden, N.M., 2001. Description and classification of soil structure using distance transform data. European Journal of Soil Science 52, 529-545.

Holmgren, G.G., 1988. The point representation of soil. Soil Science Society of America Journal 52, 712-716.

Hubbert, M.K., 1956. Darcy's law and the field equations of the flow of underground fluids. Darcy Centennial Hydrology Symposium of the International Association of Hydrology, pp. 23-59.

Hudson, B.D., 1992. The soil survey as a paradigm-based science. Soil Science Society of America Journal 56, 836-841.

Jamison, V.C., Peters, D.B., 1967. Slope length of claypan soils affects runoff. Water Resources Research 3, 471-480.

Kitchen, N.R., Sudduth, K.A., Myers, D.B., Drummond, S.T., Hong, S.Y., 2005. Delineating productivity zones on claypan soil fields using apparent soil electrical conductivity. Computers and Electronics in Agriculture 46, 285-308.

Levin, S.A., 1992. The problem of pattern and scale in ecology. Ecology 73, 1943-1967.

Levin, N., Ben-Dor, E., Singer, A., 2005. A digital camera as a tool to measure colour indices and related properties of sandy soils in semi-arid environments. International Journal of Remote Sensing 26, 5475-5492.

Lillesand, T.M., Kiefer, R.W., Chipman, J.W., 2004. Remote Sensing and Image Interpretation, 5th edition. John Wiley \& Sons, Inc, New York City, New York.

Lin, H., 2003. Hydropedology: bridging disciplines, scales, and data. Vadose Zone Journal 2, 1-11.

Littell, R.C., Milliken, G.A., Stroup, W.W., Wolfinger, R.D., Schabenberger, O., 2007. SAS for mixed models, 2nd Edition. SAS Institute, Inc., Cary, North Carolina.

McGarigal, K., Marks, B.J., 1995. FRAGSTATS: Spatial Pattern Analysis Program for Quantifying Landscape Structure. General Technical Report PNW-GTR-351, Portland, Oregon.

Mermut, A.R., 2009. Historical development in soil micromorphological imaging. Journal of Mountain Science 6, 107-112.

Minshall, N.E., Jamison, V.C., 1965. Interflow in claypan soils. Water Resources Research $1,381-390$.

Missouri Cooperative Soil Survey (MCSS), 2008. Missouri Cooperative Soil Database, Accessed March 1, 2008.

Moran, C.J., McBratney, A.B., Koppi, A.J., 1989. A rapid method for analysis of soil macropore structure. I. Specimen preparation for digital binary image production. Soil Science Society of America Journal 53, 921-928.

Morgan, C.P., Stolt, M.H., 2006. Soil morphology-water table cumulative duration relationships in southern New England. Soil Science Society of America Journal 70, 816-824.

Murphy, C.P., Bullock, P., Turner, R.H., 1977. The measurement and characterization of voids in soil thin sections by image analysis. Part I. Principles and techniques. Journal of Soil Science 28, 921-928.

Myers, D.B., Kitchen, N.R., Sudduth, K.A., Sharp, R.E., Miles, R.J., 2007. Soybean root distribution related to claypan soil properties and apparent soil electrical conductivity. Crop Science 47, 1498-1509.

O'Donnell, T.K., Goyne, K.W., Miles, R.J., Baffaut, C., Anderson, S.H., Sudduth, K.A., 2010. Identification and quantification of soil redoximorphic features by digital image processing. Geoderma 157, 86-96.

Protz, R., Sweeney, S.J., Fox, C., 1992. An application of spectral image analysis to soil micromorphology, 1. Methods of Analysis. Geoderma 53, 275-287.

Sanchez, P.A., Ahamed, S., Carrãc, F., Hartemink, A.E., Hempel, J., Huising, J., Lagacherie, P., McBratney, A.B., McKenzie, N.J., De Lourdes Mendonça-Santos, M., Minasny, B., Montanarella, L., Okoth, P., Palm, C.A., Sachs, J.D., Shepherd, K.D., Vågen, T.G., Vanlauwe, B., Walsh, M.G., Winowiecki, L.A., Zhang, G.L., 2009. Digital soil map of the world. Science 325, 680-681.

Schaetzl, R.J., Anderson, S., 2005. Soils: genesis and morphology. Cambridge University Press, New York City, New York.
Schoeneberger, P.J., Wysocki, D.A., Benham, E.C., Broderson, W.D., 2002. Field book for describing and sampling soils. Version 2.0. U.S. Department of Natural Resources Natural Resources conservation Service, Lincoln, Nebraska.

Stoops, G., 2003. Guidelines for Analysis and Description of Soil and Regolith Thin Sections. Soil Science Society of America, Madison, Wisconsin.

Stoops, G., 2009. Seventy years' "micropedology" 1938-2008: the past and future. Journal of Mountain Science 6, 101-106.

Sweeney, S.J., 1994. Macropore Characterization and Water Movement in a Fractured Glacial Till Unit of Southern Alberta. Department of Land Resource Science, University of Guelph, Canada. Ph.D. Dissertation.

Terribile, F., FitzPatrick, E.A., 1992. The application of multi-layer digital image processing techniques to the description of soil thin sections. Geoderma 55, 159-174.

Terribile, F., FitzPatrick, E.A., 1995. The application of some image-analysis techniques to recognition of soil micromorphological features. European Journal of Soil Science $46,29-45$.

Turner, M.G., 1989. Landscape ecology: the effect of pattern on process. Annual Review of Ecology and Systematics 20, 171-197.

U.S. Army Corps of Engineers Environmental Laboratory (USACE), 1987. Corps of Engineers Wetlands Delineation Manual, Vicksburg, Mississippi.

U.S. Army Corps of Engineers Environmental Laboratory (USACE), 2008. Interim Regional Supplement to the Corps of Engineers Wetland Delineation Manual: Midwest Region, Vicksburg, Mississippi.

U.S. Department of Agriculture Natural Resources Conservation Service (NRCS), 2006 Field Indicators of Hydric Soils. Washington, D.C.

U.S. Department of Agriculture Natural Resources Conservation Service (NRCS), 2009. Hydric Soils of the United States. Washington, D.C.

U.S. Department of Agriculture Soil Survey Staff (USDA), 1999. Soil Taxonomy 2nd Edition. U.S. Department of Agriculture, Washington, D.C.

van Huyssteen, C.W., le Roux, P.A.L., Hensley, M., 2006. Interpretation of digital soil photographs using spatial analysis: I. Methodology. South African Journal of Plant and Soil 23, 7-13.

VandenBygaart, A.J., Protz, R., 1999. The representative elementary area (REA) in studies of quantitative soil micromorphology. Geoderma 89, 333-346.

VandenBygaart, A.J., Protz, R., Duke, C., 2008. Digital image analysis of soil micromorphology. In: Ulrey, A.L., Drees, L.R. (Eds.), Methods of Soil Analysis. Part 5. Mineralogical Methods. Soil Science Society of America, Madison, Wisconsin, pp. 22-234.

Velde, B., Moreau, E., Terrible, F., 1996. Pore networks in an Italian vertisol: quantitative characterisation by two dimensional image analysis. Geoderma 72, 271-285.

Veneman, P.L.M., Spokas, L.A., Lindbo, D.L., 1998. Soil moisture and redoximorphic features: a historical perspective. In: Rabenhorst, M.C., Bell, J.C., McDaniel, P.A (Eds.), Quantifying Soil Hydromorphology. SSSA Special Publication Number 54 Soil Science Society of America, Madison, Wisconsin, pp. 1-23.

Vepraskas, M.J., 2001. Morphological Features of Seasonally Reduced Soils. Genesis, hydrology, landscapes, and classification, Wetland soils.

Vepraskas, M.J., Caldwell, P.V., 2008. Interpreting morphological features in wetland soils with a hydrologic model. Catena 73, 153-165.

Vepraskas, M.J., Wilson, M.A., 2008. Soil micromorphology: concepts, techniques, and applications. In: Ulrey, A.L., Drees, L.R. (Eds.), Methods of Soil Analysis. Part 5. Mineralogical Methods. Soil Science Society of America, Madison, Wisconsin, pp. 191-225.

Viscarra Rossel, R.A., Fouad, Y., Walter, C., 2008. Using a digital camera to measure soil organic carbon and iron contents. Biosystems Engineering 100, 149-159.

Wilding, L.P., Flach, K.W., 1985. Micropedology and soil taxonomy. In: Douglas, L.A., Thompson, M.L. (Eds.), Soil Micromorphology and Soil Classification. Soil Science Society of America, Madison, Wisconsin, pp. 1-16.

Woods, E.F., Sivapalan, M., Beven, K., Band, L., 1988. Effects of spatial variability and scale with implications to hydrological modeling. Journal of Hydrology 102, 29-47.

Zampella, R.A., 1994. Morphologic and color pattern indicators of water table levels in sandy pineland soils. Soil Science $157,312-317$. 